\title{
Taphonomy of Isocrinid Stalks: Influence of Decay and Autotomy
}

Tomasz K. Baumiller

Harvard University

Ghislaine Llewellyn

Harvard University

Charles G. Messing

Nova Southeastern University, messingc@nova.edu

William I. Ausich

Ohio State University

Find out more information about Nova Southeastern University and the Halmos College of Natural Sciences and Oceanography.

Follow this and additional works at: https://nsuworks.nova.edu/occ_facarticles

Part of the Marine Biology Commons, and the Oceanography and Atmospheric Sciences and Meteorology Commons

\section{Recommended Citation}

Baumiller, Tomasz K., Ghislaine Llewellyn, Charles G. Messing, and William I. Ausich. "Taphonomy of isocrinid stalks; influence of decay and autotomy." Palaios 10, no. 1 (1995): 87-95.

This Article is brought to you for free and open access by the Department of Marine and Environmental Sciences at NSUWorks. It has been accepted for inclusion in Marine \& Environmental Sciences Faculty Articles by an authorized administrator of NSUWorks. For more information, please contact nsuworks@nova.edu. 


\section{Taphonomy of Isocrinid Stalks: Influence of Decay and Autotomy}

\author{
TOMASZ K. BAUMILLER \\ Department of Earth and Planetary \\ Sciences, \\ Harvard University, \\ 20 Oxford St., \\ Cambridge, MA 02138, U.S.A. \\ GHISLAINE LLEWELLYN \\ Department of Earth and Planetary \\ Sciences, \\ Harvard University, \\ 20 Oxford St., \\ Cambridge, MA 02138, U.S.A. \\ CHARLES G. MESSING \\ Nova University Oceanographic \\ Center, \\ 8000 North Ocean Drive, \\ Dania, FL 33004, U.S.A. \\ WILLIAM I. AUSICH \\ Department of Geological Sciences, \\ Ohio State University, \\ 155 S. Oval Mall, \\ Columbus, OH 43210, U.S.A.
}

PALAIOS, 1995 , V. 10 , p. 87-95

Stalks of isocrinid crinoids are differentiated into cirri-bearing columnals (nodals) and columnals lacking cirri (internodals). This skeletal differentiation allowed us to test whether stalk fragmentation is random or whether it occurs preferentially at a specific articulation. Our analyses indicate that the patterns of fragmentation in multicolumnal segments of extant isocrinids collected by submersible, by dredging, and in sediment samples, as well as those found as fossils, are nonrandom. The preferred plane of fragmentation corresponds to the synostosis, the articulation between a nodal and the internodal distal to $i$ it. In isocrinids this articulation has a characteristic morphology and is the site of autotomy.

Although stalk shedding by autotomy may contribute to the observed patterns, decay experiments on isocrinid stalks, both in situ and in the lab, suggest that post-mortem disarticulation also results in nonrandom fragmentation. Thus both processes, autotomy and post-mortem decay, contribute to the observed pattern of fragmentation. Underlying both processes is the organization of soft tissues at synostoses.

\section{INTRODUCTION}

The recent use of submersibles for the study of stalked crinoids has produced a wealth of data on the ecology, morphology, and biostratinomy of these animals (Macurda and Meyer, 1974; Roux, 1980a, b; Conan et al., 1981; Messing et al., 1988; Holland et al., 1991; Baumiller et al., 1991; Llewellyn and Messing, 1994). Isocrinids have been the focus of most of the ecological and biostratinomic research, whereas the morphology of representatives of all 5 living orders of crinoids has been studied in detail (Grimmer et al., 1984a, b; 1985; Grimmer and Holland, 1990; Holland et al., 1991). These data have given us a better, though in comparison to other invertebrate groups still rather rudimentary, understanding of living crinoids, which is critical for interpreting fossil crinoids. Fossil crinoid stalks, for example, have often been used for systematic, taxonomic, and biostratigraphic purposes (Gluchowski, 1981; Hagdorn, 1983, 1986; Moore and Jeffords, 1968; Schubert et al., 1992; Simms, 1989; Stukalina, 1988). These approaches have generally relied on interpretations of skeletal morphology. In recent years, however, studies on soft-part anatomy of stalks of living crinoids (Grimmer et al., 1984a, b, 1985; Grimmer and Holland, 1990; Holland et al., 1991) have provided a new perspective to paleobiologists studying crinoid stalks. For example, Donovan (1989) used the absence of muscles in stalks of living crinoids and hardpart morphology of fossils to argue that fossil crinoid stalks also lacked muscles; Baumiller and Ausich (1992) used the distribution of ligaments in living isocrinids to interpret the pattern of fragmentation of Mississippian stalks. These examples illustrate how data on living crinoids can help generate paleontological hypotheses.

This study is a further example of this approach. We used data on the morphology and behavior of living isocrinids to test the hypothesis that there is a preferred site of disarticulation in their stalks. To test this hypothesis we examined stalks of extant isocrinids and subjected a series of them to a set of experimental treatments. Having established that a preferred site of disarticulation exists, we then examined Mesozoic and Cenozoic isocrinid stalks to determine if, in these fossil specimens, the site of disarticulation was the same as in living isocrinids.

\section{ISOCRINID STALK \\ MORPHOLOGY, AUTOTOMY, AND BIOSTRATINOMY}

The soft- and hard-part structure of isocrinid stalks has been studied in detail by several investigators (Macurda and Meyer, 1975; Roux, 1974, 1975, 1977; Donovan, 1984; Grimmer et al., 1985). The isocrinid stalk is organized into two distinct regions: a short proximal growing region in which new columnals develop, and a distal region in which columnal arrangement and size remain constant. Two types of columnals can be distinguished in the stalk: the nodals, which bear appendages called cirri, and the internodals, which lack cirri. In external appearance the isocrinid stalk consists of repeating segments (noditaxes), each composed of a set 
of internodals bounded on its distal end by a cirri-bearing nodal (Fig. 3A in Baumiller and Ausich, 1992). Each segment contains approximately equal numbers of columnals, except for the proximal region where new internodals are intercalated.

The regular pattern of the noditaxis skeletal morphology is also reflected in the organization of isocrinid soft tissues (Grimmer et al., 1985). In each noditaxis, long ligament fibers, called through-going ligaments, pass through the stereom of the internodals and into the nodal where they terminate (Fig. 3B in Baumiller and Ausich, 1992). Only short ligament fibers, called intercolumnal ligaments, penetrating no deeper than tens of microns into the stereom, connect the nodal to the adjacent distal internodal, called the infranodal. This pattern is then repeated in the subsequent noditaxis. Thus the stalk is subdivided into noditaxes, each held together by long ligaments and connected to other noditaxes by articulations bearing only short ligament fibers. The latter type of articulation is called the synostosis. The synostosis is easily distinguished from other types of articulations (symplexies) in living and fossil isocrinids because of its relatively featureless skeletal morphology (Hagdorn, 1983; Donovan, 1984).

Observations of living isocrinids in situ and in the lab have shown that distal parts often disarticulate from the rest of the stalk (Baumiller et al., 1991). When such disarticulation occurs, it invariably does so at a synostosis. As a result, the most distal columnal of the stalk is a cirri-bearing nodal. The disarticulation of parts of the stalk in a living animal has been interpreted as autotomy and the synostosis is judged to be the articulation specialized for autotomy (Roux, 1974, 1977; Emson and Wilkie, 1980; Wilkie and Emson, 1988; Oji, 1989).

The details of how crinoids autotomize stalk segments have not been worked out, but it is believed that the mutable collagenous tissue (MCT) composing the ligaments must be involved in this process (Emson and Wilkie, 1980; Motokawa, 1984; Wilk- ie, 1984). The physical properties of the MCT's, such as stiffness and viscosity, may be controlled by the organism; autotomy may involve the active reduction of the stiffness and/ or viscosity of the ligament. It is not known why or how frequently autotomy of stalk segments occurs. If shedding of distal stalk segments is frequent, the majority of multicolumnal segments (pluricolumnals) found in the sediment should terminate distally at a nodal rather than an internodal.

Alternatively, a pattern of nodalterminated pluricolumnals could be produced by another mechanism: the differential resistance of synostosial and non-synostosial articulations to decay. Baumiller and Ausich (1992) argued that synostoses, because they lack thicker, through-going ligaments and because they may bear special structures facilitating autotomy, would be the first to disarticulate following death, thus producing nodal-terminating pluricolumnals. Decay experiments on four short stalk fragments of the isocrinid Cenocrinus asterius (Linné) confirmed this prediction: the stalk segments disarticulated first at the synostosial articulations, while the other articulations remained intact for several days longer.

These results, and the observations of living crinoids in situ and in the lab, suggest that isocrinid pluricolumnals in modern sediments and as fossils should be characterized by nodal-terminated segments. Alternatively, if the processes of differential decay and/or shedding are unimportant, the pluricolumnals found should be terminated at a random columnal, i.e., either at a nodal or at an internodal. Since, in a given stalk, the number of internodals exceeds the number of nodals by approximately an order of magnitude, a random pattern of disarticulation would produce many more pluricolumnals terminating in internodals than in nodals. The goal of this study is to test whether the pluricolumnals in experimental and natural settings, and those preserved as fossils, exhibit the expected non-random pattern, i.e., with the nodal as the distalmost (terminal) columnal.

\section{LABORATORY EXPERIMENTS}

The decay experiments conducted by Baumiller and Ausich (1992) were limited in scope: only four incomplete stalk segments were used, the specimens had been frozen prior to the experiments, the complete sequence of disarticulation was observed over a period of only 6 days, with only a single specimen observed during an additional 15-day period and under modified experimental conditions, and only a single species was tested. In an attempt to extend and confirm those results, the decay sequences of 12 specimens of two different isocrinid species [(Endoxocrinus parrae (Gervais) and Chladocrinus decorus (Carpenter)] were observed for up to 60 days (Fig. 1). The specimens were placed in 60-liter, aerated, sea-water tanks and maintained in the dark at either 18 or $20^{\circ}$ C. They were monitored daily and the patterns of fragmentation were recorded. The results largely confirm the conclusions of the previous study (Baumiller and Ausich, 1992): the synostoses fragmented before the symplexies (articulations between internodals) did, yielding isolated noditaxes; but unlike the previous study in which all synostoses fragmented before any of the symplexies did, in this instance some synostoses remained intact longer than several of the symplexies.

To statistically test whether synostoses have a higher probability of fragmentation, the observed patterns of disarticulation were compared to patterns expected under the null hypothesis of an equal probability of fragmentation for all articulations $\left(\mathrm{H}_{0}\right.$ : probability of synostosial break $=$ probability of symplectial break). To obtain the patterns expected under the null model, the disarticulation of each of the 12 stalks used in the experiments was simulated by a QuickBASIC program. The articulations at which fragmentation occurred were selected by a random number generator and a running count was kept of how many of the 
breaks were synostoses (the initial ratio of synostoses to symplexies was 1:10 for Endoxocrinus parrae and 1:14 for Chladocrinus decorus). As the number of breaks in the simulation reached a stage of disarticulation corresponding to that in the experiment, a comparison was made between the simulated and the observed pattern. If the number of broken synostoses was smaller in the simulation, the simulation was counted as "non-random"; otherwise it was counted as "random." This procedure was continued until the number of simulated breaks corresponded to the maximum number of breaks in the given experiment. The entire procedure was repeated 1000 times, keeping "non-random" and "random" scores. If after 1000 simulations the "random" score was lower than 50 (corresponding to a "nonrandom" score greater than 950), the null hypothesis was rejected at $\mathrm{P}<$ 0.05 . By repeating the simulations for each of the 12 stalks, it was possible to determine for which, if any, stages of disarticulation the "random" model could be rejected.

The results, shown in Figure 2, suggest that in almost all stages of disarticulation in nearly all stalks, the "random" model can be rejected, i.e., that synostoses have a higher probability of disarticulation. Generally, the model cannot be rejected only in the initial and final stages of disarticulation. But this is as expected, since for the very first break the random probability of it corresponding to a synostoses is $1 / 10(0.1)$ for $E n$ doxocrinus parrae and $1 / 14(0.07)$ for Chladocrinus decorus, i.e., for both taxa it is higher than the 0.05 threshold for rejecting the random model. Likewise, as disarticulation proceeds to completion past the stage at which all synostoses had been broken and symplexies begin to disarticulate, the random probability again approaches $1 / 10$ for $E$. parrae and $1 / 14$ for $C$. decorus and the random model cannot be rejected.

In conclusion, the results of the decay experiments confirm that the synostosis is the plane of post-mortem weakness, that it preferentially disarticulates during decay, and that

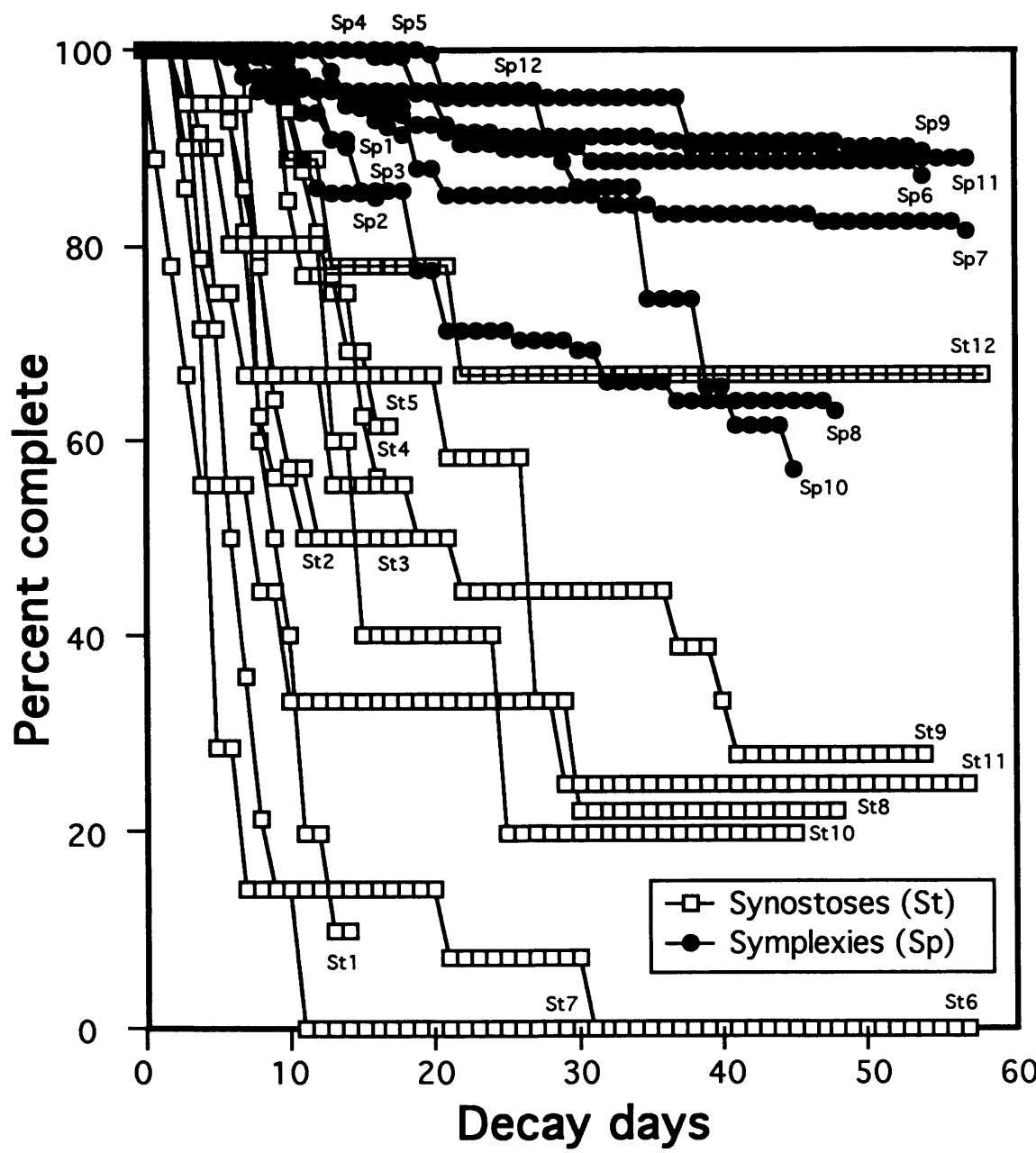

FIGURE 1-Results of decay experiments on Endoxocrinus parrae and Chladocrinus decorus. The total number of synostosial $\left(\mathrm{St}_{0}\right)$ and symplectial $\left(\mathrm{Sp}_{0}\right)$ articulations was counted in each specimen at the start of the experiment. The degree of fragmentation of each type of articulation is plotted through time. Fragmentation is expressed for each specimen as the ratio of number of fragmented articulations to the total number of such articulations: synostoses $=\mathrm{St}=\mathrm{St}_{\text {disart }}$ / $\mathrm{St}_{0}$; symplexies $=\mathrm{Sp}=\mathrm{Sp}_{\mathrm{disar}} / \mathrm{Sp}_{0}$. The subscripts correspond to different individuals. $C$. decorus at $20^{\circ} \mathrm{C}$ : St1, Sp1; St2, Sp2; St3, Sp3; St7, Sp7: E. parrae at $20^{\circ} \mathrm{C}: \mathrm{St4}, \mathrm{Sp4}$; St5, Sp5; St6, Sp6; E. parrae at $18^{\circ} \mathrm{C}$ : St8, Sp8; St9, Sp9; $C$. decorus at $18^{\circ}$ C: St10, Sp10; St11, Sp11; St12, Sp12.

the resulting pattern of pluricolumnals should be dominated by those terminating on a nodal (Fig. 3A).

\section{IN SITU EXPERIMENTS AND STATISTICAL ANALYSES}

To determine whether the predicted pattern of stalk segments terminating on nodals can be observed in nature, we performed an additional experiment and examined dredged specimens and sediment samples col- lected in the vicinity of living isocrinids.

In the in situ experiment, we collected live Endoxocrinus parrae and Chladocrinus decorus via a suction hose apparatus on the submersible Johnson Sea Link in 420-430 m south of West End, Grand Bahama Island (see Llewellyn and Messing, 1994 for study site details). Specimens of both species were placed, either live or sacrificed (by freezing), inside pantyhose (Hanes ${ }^{\circledR}$ ) legs, tied off, weight- 


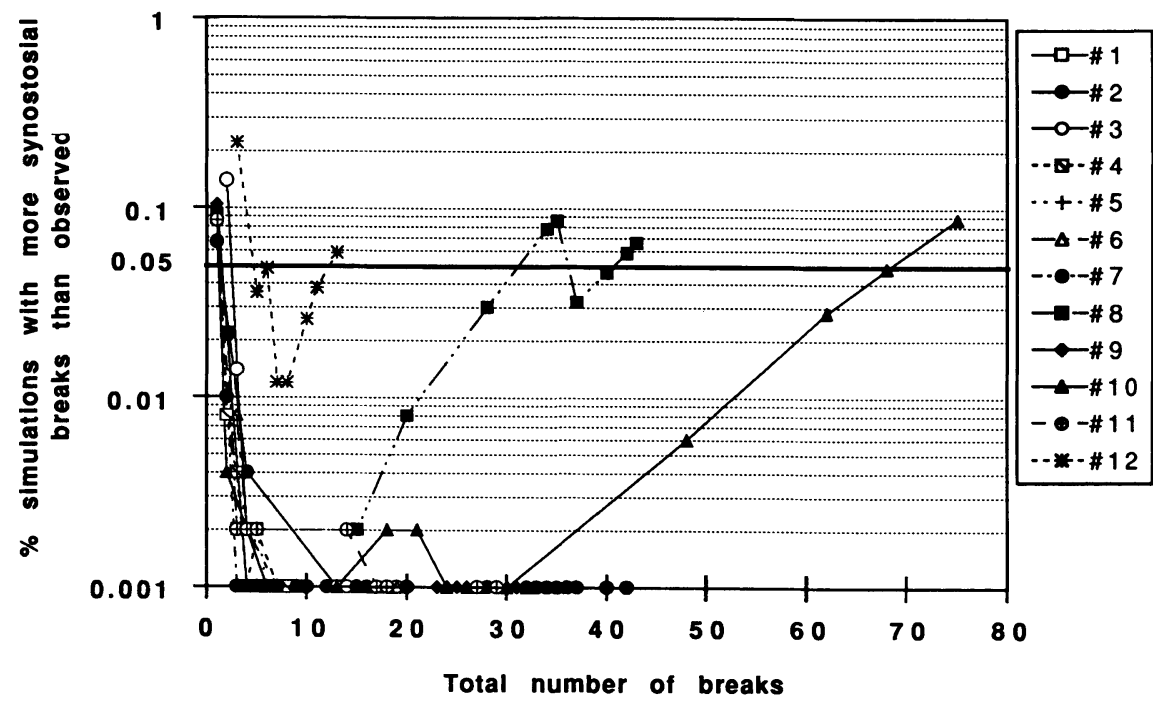

FIGURE 2-Comparison of patterns of fragmentation of simulated stalks to experimentally decayed stalks. The data represent the comparison of 1000 computer simulations generated under the null model (no differences in probability of fragmentation between synostoses and symplexies) to data from lab decay experiments. The heavy horizontal line corresponds to 50 simulations with an equal or a greater number of disarticulated synostoses than observed in the decay experiments; for data below the line, the null model is rejected at $P<0.05$. The numbers in the legend correspond to the stalks listed in Figure 1.

ed from a plastic-covered SCUBA weight, and returned to the collection site. The pantyhose fabric allowed ambient water to circulate around the crinoid carcass while providing a means of retaining the products of taphonomic breakdown. Three specimens were recovered after 2 months and two after 5.5 months.

The arms and calyx of all specimens dissociated completely, but even for those remaining at the site for 5.5 months, some articulated stalk segments were recovered. In the majority $(60 / 73)$ of recovered nodalbearing segments, the nodal was at the terminal end (Table 1).

To assess whether the observed pattern was consistent with a random or a non-random pattern of breakage, we formulated and tested a null hypothesis in which the pattern was random. Under this random model, every articulation has an equal probability of fragmentation. For a pluricolumnal consisting of $x$ plates, there is an equal probability $(1 / \mathbf{x})$ that any of the plates will lie at its distal end. If only one of these plates is a nodal, there is a $1 / x$ probability that the pluricolumnal will terminate in a nodal. Correspondingly, the probability that the pluricolumnal terminates in an internodal is $(x-1) / x$. For a segment consisting of 5 plates, a nodal and 4 internodals, there is a $20 \%$ probability that the distal plate is a nodal; for a segment with 7 internodals and a nodal, that probability is $12.5 \%$. The probability that both segments terminate at a nodal is 0.025 , i.e., the product of probabilities for individual segments $(0.125$ $\times 0.2$ ). If a third pluricolumnal, consisting of only three columnals, is considered, the probability that all three possess a nodal at the distal end is $0.008(0.33 \times 0.125 \times 0.2)$. If these three pluricolumnals constituted our sample, we would reject the null hypothesis at $P<0.01$, and conclude that the pattern is more consistent with the scenario that fragmentation is more likely at the synostosis. If, however, the third pluricolumnal terminated at an internodal, testing for non-randomness would prove more difficult. We chose the conservative approach and asked the following question: assuming all three segments were of equal length and that the length corresponds to the short- est segment ( 3 columnals in our example), what is the probability that 2 of these segments would terminate in a nodal? We can apply the binomial equation to answer this question:

$$
P(x)=\frac{n !}{x !(n-x) !} p^{x} q^{n-x}
$$

where $P(x)$ is the probability that the event will occur $x$ times in $\mathbf{n}$ trials; $p$ is the probability that the event will occur in any given trial; and $q=1-$ $p$ is the probability of the event not occurring. In our example, $x=2, n$ $=3$, and, since we have made the assumption that all segments are of equal length of 3 columnals, one of which is a nodal, $p$, the probability that a nodal lies at the distal end in any of these segments, is $1 / 3$, while $q$, the probability that an internodal is at the distal end, is $2 / 3$. The value of $\mathrm{P}(\mathrm{x})$ in this example is 0.26 ; thus we cannot reject the null hypothesis and must conclude that the sample of three pluricolumnals represents a random pattern of breakage. The approach is conservative because the shortest pluricolumnal is used to calculate the values of $p$ and $q$; in the extreme case of a pluricolumnal consisting of two plates, a nodal and an internodal, both $p$ and $q$ would have a value of 0.5 . This approach therefore overestimates the value of $p$ and underestimates the value of $q$ for all pluricolumnals in the sample except the shortest one. The calculated $\mathrm{P}(\mathrm{x})$ is therefore maximized, making it more difficult to reject the null hypothesis.

The above approach can be applied to any sample of pluricolumnals by obtaining the values of $n$, the number of pluricolumnals with at least a single nodal, of $x$, the number of pluricolumnals with a nodal at the distal end, and of $p$, which is the ratio of nodals to total number of columnals in the shortest specimen in the sample. For a sample in which all pluricolumnals contain more than a single nodal, $p$ is just the reciprocal of the number of plates in an individual noditaxis.

When applied to the data from the pantyhose experiment, the statistical 
test confirms the initial impression: when taken together, 60 of 73 nodalbearing segments terminated in a nodal, and even under the most conservative assumption of 2 columnals/ segment, the random model was rejected at $P<0.001$ (Table 1). The synostosis is thus the preferred site of disarticulation.

\section{PLURICOLUMNALS IN \\ SEDIMENT SAMPLES, AND \\ STALKS OF DREDGED AND \\ COLLECTED SPECIMENS}

Sediment samples were collected in the same area and depth and by the same means as the live specimens in the pantyhose experiment (see Llewellyn and Messing, 1994 for details of sampling). The submersible's standard collecting buckets were covered with 0.0625 -inch ${ }^{2}$ plastic mesh which retained the coarse sediment fraction. Following ascent, retrieved sediment was preserved in alcohol and subsequently washed through a standard series of sieves. The majority of retrieved crinoidal material $(\geq 2$ $\mathrm{mm}$ ) consisted of individual crinoid columnals; pluricolumnals were rare. The suction apparatus is sufficiently powerful to pick up complete isocrinids and even pieces of rubble, so it is unlikely that individual columnals were preferentially sampled. Of the retrieved nodal-bearing pluricolumnals, 25 terminated at nodals and 1 at an internodal (Table 2). Again, using the binomial test described above, the pattern of disarticulation was non-random with respect to articulation type: synostoses were more susceptible to fragmentation.

The preferred disarticulation of synostosial articulations was tested with two additional data sets consisting of dredged and collected specimens of isocrinids. The Museum of Comparative Zoology (Harvard University) houses isocrinid specimens dredged from a depth of 176-248 m in the vicinity of St. Vincent, eastern Caribbean, by the Blake expedition in 1878-1879 (MCZ 8; MCZ 232; MCZ 269). Several of these were preserved in alcohol, but a majority were dried. Although many crowns and arm clusters are available, the majority of the
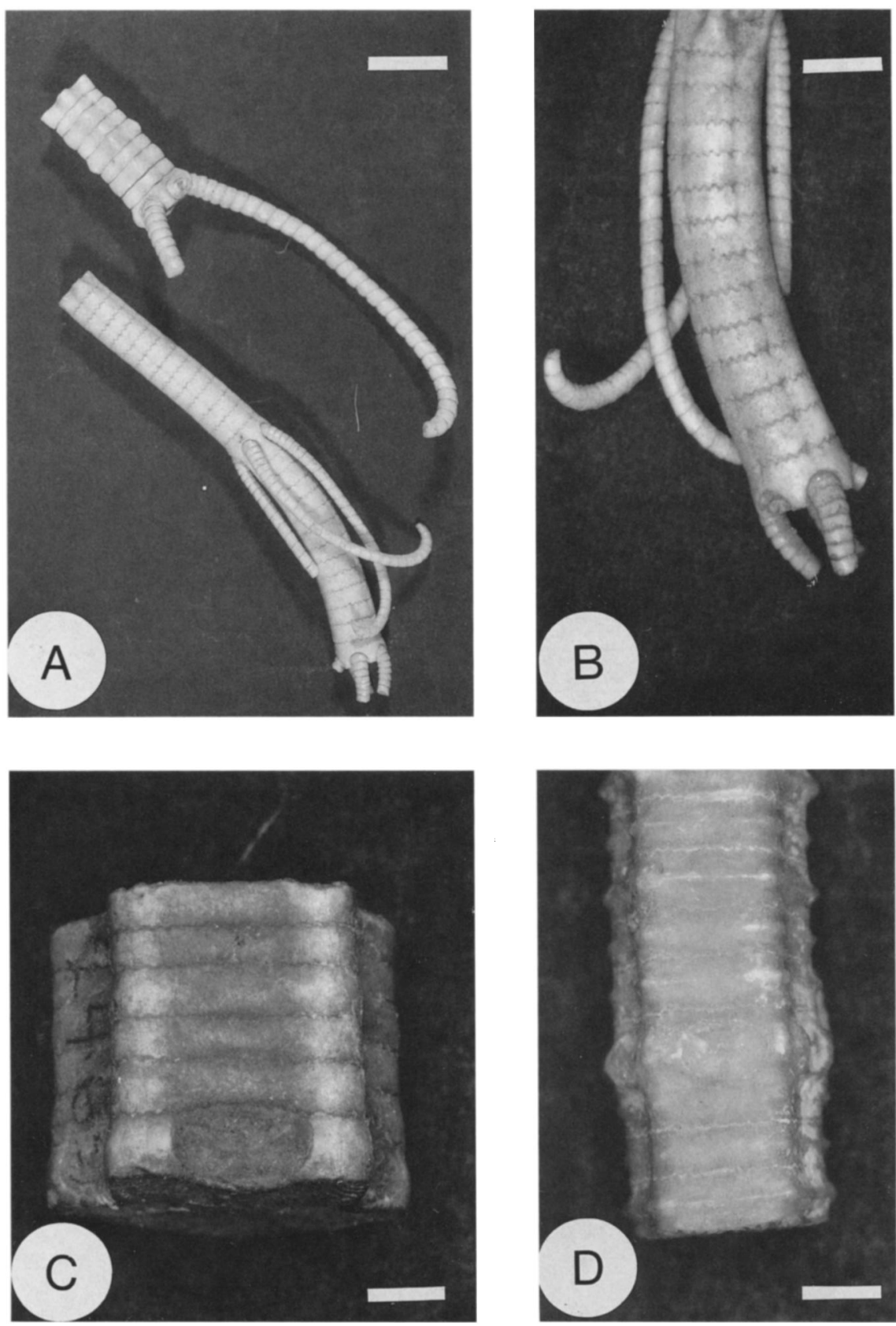

FIGURE 3-A. Two examples of pluricolumnals of Endoxocrinus parrae(top) and Chladocrinus decorus (bottom) following the decay treatment. Note that the proximal end in both specimens is an infranodal and the terminal end a nodal (scale bar $=0.25 \mathrm{~mm}$ ). B. One of the specimens of $C$. decorus collected during the Blake expedition. The terminal end is a nodal. (scale bar $=0.31 \mathrm{~mm}$ ). C. A noditaxis of a Jurassic isocrinid terminating at a nodal. Pentacrinus scalaris Goldfuss; MCZ 2463. (scale bar $=0.20 \mathrm{~mm}$ ). D. An isocrinid pluricolumnal with nodal not at the terminal end. Pentacrinus cingulatus Goldfuss; MCZ 137.5. (scale bar $=0.17 \mathrm{~mm}$ ).

specimens consist of stalk fragments of various lengths. Fragmentation of the stalks may have occurred prior to, during, or after dredging, and these data undoubtedly represent a summation of processes including autotomy, post-mortem decay, and mechanical breakage caused by 
TABLE 1-Results of in situ taphonomy experiments.

\begin{tabular}{|c|c|c|c|c|}
\hline & $\begin{array}{l}\text { Segments } \\
\text { with nodal }\end{array}$ & $\begin{array}{l}\text { Termi- } \\
\text { nating in } \\
\text { nodal }\end{array}$ & $\begin{array}{l}\text { Terminat- } \\
\text { ing in } \\
\text { internodal }\end{array}$ & $\begin{array}{l}\text { Probability } \\
\text { of random } \\
\text { fragmentation }\end{array}$ \\
\hline Chladocrinus decorus & 15 & 15 & 0 & $3.1 \times 10^{-5}$ \\
\hline Chladocrinus decorus & 18 & 10 & 8 & $4.0 \times 10^{-1}$ \\
\hline Endoxocrinus parrae & 15 & 11 & 4 & $6.0 \times 10^{-2}$ \\
\hline Endoxocrinus parrae & 10 & 10 & 0 & $1.0 \times 10^{-3}$ \\
\hline Endoxocrinus parrae & 15 & 14 & 1 & $5.0 \times 10^{-4}$ \\
\hline Total & 73 & 60 & 13 & $1.1 \times 10^{-8}$ \\
\hline
\end{tabular}

TABLE 2-Patterns of fragmentation in specimens obtained from sediment samples.

\begin{tabular}{|c|c|c|c|c|}
\hline & $\begin{array}{l}\text { Segments } \\
\text { with nodal }\end{array}$ & $\begin{array}{c}\text { Termi- } \\
\text { nating in } \\
\text { nodal }\end{array}$ & $\begin{array}{c}\text { Terminat- } \\
\text { ing in } \\
\text { internodal }\end{array}$ & $\begin{array}{l}\text { Probability } \\
\text { of random } \\
\text { fragmentation }\end{array}$ \\
\hline Chladocrinus decorus & 14 & 14 & 0 & $6.1 \times 10^{-5}$ \\
\hline Endoxocrinus parrae & 12 & 11 & 1 & $3.1 \times 10^{-3}$ \\
\hline Total & 26 & 25 & 1 & $4.0 \times 10^{-7}$ \\
\hline
\end{tabular}

TABLE 3-Patterns of fragmentation in specimens dredged by the "Blake" expedition.

\begin{tabular}{lcccc}
\hline \hline & & $\begin{array}{c}\text { Terminat- Terminat- } \\
\text { Segments } \\
\text { ing in } \\
\text { with nodal }\end{array}$ & $\begin{array}{c}\text { Probability } \\
\text { ing in } \\
\text { of random } \\
\text { fragmentation }\end{array}$ \\
\hline Chladocrinus decorus & 291 & 186 & 105 & $1.2 \times 10^{-6}$ \\
\hline
\end{tabular}

TABLE 4-Types of columnals found at the distal end of isocrinid stalks collected by submersible.

\begin{tabular}{|c|c|c|c|c|}
\hline & $\begin{array}{l}\text { Number } \\
\text { of stalks }\end{array}$ & $\begin{array}{l}\text { Terminat- } \\
\text { ing in } \\
\text { nodal }\end{array}$ & $\begin{array}{c}\text { Termi- } \\
\text { nating } \\
\text { in inter- } \\
\text { nodal }\end{array}$ & $\begin{array}{c}\text { Probability } \\
\text { of random } \\
\text { fragmentation }\end{array}$ \\
\hline Chladocrinus decorus & 72 & 62 & 10 & $1.3 \times 10^{-10}$ \\
\hline Endoxocrinus parrae & 94 & 81 & 13 & $1.8 \times 10^{-13}$ \\
\hline Diplocrinus maclearanus & 14 & 13 & 1 & $9.1 \times 10^{-4}$ \\
\hline Total & 180 & 156 & 24 & 0 \\
\hline
\end{tabular}

handling. We repeated the procedure used with previous data on these stalk segments and a majority, 105 out of a total of 186 , terminated at nodals
(Fig. 3B; Table 3). Using the conservative assumption of 2 nodals/segment, the random model of breakage was rejected $(P<0.001)$. The same approach was applied to 180 specimens (crowns with column attached of 3 isocrinid species collected via the Johnson Sea-Link in 265-530 m off Grand Bahama Island (Messing and Llewellyn, in prep.). In 156 of these specimens, the nodal was the terminal column (Table 4); this again indicates non-random fragmentation even under the most conservative assumption $(P<0.001)$.

The above examples demonstrate that in nature, as in the laboratory, a preferred plane of stalk disarticulation exists and corresponds to the synostosis. It is not possible to discriminate between those segments produced by autotomy, disarticulation or mechanical breakage, but the overall pattern is non-random.

\section{DISARTICULATION PATTERNS IN FOSSIL ISOCRINID STALKS}

Although counts of stalks subjected to experimental and natural conditions confirm predictions based on morphological analysis, i.e., that synostoses are the preferred sites of disarticulation, these results are not sufficient to conclude that fossil isocrinid stalks ought to exhibit the same patterns. Actualistic results may not be applicable to fossil material for at least two reasons: (1) biostratinomic patterns can be smeared or altered during burial and fossilization, and (2) fossilized taxa may have had different soft-tissue morphology, resulting in different taphonomic behavior. To determine whether the actualistic results could be extended to the fossil record, we examined collections of fossil isocrinid pluricolumnals from the MCZ and the $\mathrm{Na}$ tional Museum of Natural History, Smithsonian Institution (NMNH). These collections of stems are from numerous localities throughout Europe and range in age from Triassic to Eocene. The pluricolumnals represent a variety of isocrinid species and were probably collected non-randomly; it is likely that longer pluricolumnals were preferentially selected. It is highly unlikely, however, that the collectors exhibited any bias for segments terminating in nodals; in- 
stead, they probably collected long pluricolumnals indiscriminately. Since the presence of cirral scars allows for the recognition of nodals in fossils even when no cirri are preserved, the frequency of segments terminating in nodals versus internodals could be determined from the specimens. Thus, we were able to repeat the procedure used in the previous experiments, to determine the frequency of the two types of segment. We selected all isocrinid pluricolumnals which allowed us to test the hypothesis that synostoses are the preferred sites of disarticulation. The sample thus included all pluricolumnals in which a nodal was present (Appendix 1). Just as in the actualistic examples, the majority of fossil pluricolumnals terminated at nodals (384 of 410) (Fig. 3C, D; Table $5)$. The statistical analysis confirmed that the pattern was not consistent with a random model even under the most conservative assumption of 2 columnals/segment $\left(\mathrm{H}_{0}\right.$ rejected at $\mathrm{P}$ $<0.001$ ). The synostoses, once again, prove to be the preferred sites of disarticulation.

\section{DISCUSSION AND CONCLUSION}

By investigating multi-columnal segments from living and fossil isocrinid stalks, a non-random pattern has been revealed. The majority of isocrinid pluricolumnals terminate at a nodal, though this columnal is under-represented relative to internodals in all isocrinids. At least two mechanisms could be responsible for generating this pattern: shedding, by autotomy, of distal noditaxes by the living organism, or lower post-mortem resistance of the synostosis to disarticulation.

Whether shedding of stalk fragments occurs in nature has not been determined, but indirect evidence suggests that such shedding does occur: the stalks of dredged isocrinids and those collected by submersible commonly break and the breaks coincide with a synostosis (Rasmussen, 1977). This could be attributed to the lower strength of this articulation as argued by Rasmussen (1977), but the stalk breaks even when no force is

TABLE 5-Patterns of fragmentation in fossil pluricolumnals.

\begin{tabular}{|c|c|c|c|c|}
\hline & $\begin{array}{l}\text { Segments } \\
\text { with nodal }\end{array}$ & $\begin{array}{l}\text { Terminating } \\
\text { in nodal }\end{array}$ & $\begin{array}{l}\text { Terminating } \\
\text { in internodal }\end{array}$ & $\begin{array}{l}\text { Probability } \\
\text { of random } \\
\text { fragmen- } \\
\text { tation }\end{array}$ \\
\hline NMNH collection & 159 & 140 & 19 & 0 \\
\hline MCZ collection & 244 & 238 & 6 & 0 \\
\hline Total & 403 & 378 & 25 & 0 \\
\hline
\end{tabular}

applied; it is more likely that the animal is actively shedding parts of the stalk under unfavorable conditions. Shedding has also been used to explain why the isocrinid Metacrinus rotundus possesses a relatively short stalk in spite of its unusually high growth rate (Oji, 1989). Shedding may be supported by the fact that there is no distal taper in stalks of large isocrinid specimens, whereas small individuals may display a distal taper in column diameter. Since the most distal columnals are formed during early stages of ontogeny, their diameter should be the smallest. The lack of a distal taper in large individuals suggests that the oldest columnals have been shed. An alternative explanation would require an increasing proximal to distal radial growth gradient. Shedding is a more likely explanation and deserves future attention.

The pattern of post-mortem disarticulation has been demonstrated with experiments, both in situ and in the lab. The actual mechanism responsible has not been identified; Baumiller and Ausich (1992) proposed that symplexies may be more resistant because of the presence of through-going ligaments or because structures promoting autotomy at synostoses reduce the integrity of ligaments even after death. Again, more research is required to identify which of these two mechanisms is responsible.

The greater frequency of nodalterminating pluricolumnals may be the result of both processes, shedding and post-mortem disarticulation. Both processes reflect the same underlying cause: the organization of soft tissues at synostoses. This mode of soft-tissue organization must have been present in Triassic isocrinids, as is suggested by their patterns of fragmentation. Thus, among these early isocrinids, skeletal differentiation (synostoses/symplexies) (Hagdorn, 1983; Simms, 1988) and soft-tissue differentiation were both present. A question which we cannot answer with certainty, however, is whether softtissue differentiation preceded the evolution of synostoses among the articulates. Baumiller and Ausich (1992) have suggested that some Mississippian crinoid stalks, while lacking skeletal differentiation, possessed soft-tissue organization analogous, or homologous, to the isocrinids. They further argued that the ability to autotomize need not be associated with a skeletal signature. Their conclusion needs further testing, but if correct, would make the recognition of autotomy in fossils much more difficult. Yet autotomy is an important trait not only because of its biomechanical and paleoecological implications, but also because it could prove to be a useful character for phylogenetic analyses. However, if this trait cannot be recognized on purely morphological criteria, other means must be used for its identification. The pattern of fragmentation method used by Baumiller and Ausich (1992) is applicable only in very special circumstances, while the methods used in this study still essentially rely on recognition of skeletal differences. Other methods for recognizing autotomy, such as additional non-random patterns of fragmentation or geochemical signatures associated with autotomy planes, may be available but need testing with living and fossil material. 


\section{ACKNOWLEDGMENTS}

We thank F. Collier (MCZ) and J. Thompson (NMNH) for access to the collections; the staff of Harbor Branch Oceanographic Institute for help with collection of specimens and samples; A. Pei for technical help; and H. Hagdorn, M. LaBarbera, and 2 reviewers for useful comments. This study was funded in part by grants from the National Science Foundation (EAR 9104892 to W.I.A. and T.K.B., and EAR 9004232 to C.G.M.).

\section{REFERENCES}

Baumiller, T.K., and Ausich, W.I., 1992 , The broken-stick model as a null hypothesis for crinoid stalk taphonomy and as a guide to the distribution of connective tissue in fossils: Paleobiology, v. 18, p. 288-298.

Baumiller, T.K., Labarbera, M., and WoodLEY, J.D., 1991, Ecology and functional morphology of the isocrinid Cenocrinus asterius (Echinodermata): In situ and laboratory experiments and observations: Bulletin of Marine Science, $v$. 48, p. 731-748.

Conan, G., Roux, M., and Sibuet, M., 1981, A photographic survey of the stalked crinoid Diplocrinus (Annacrinus) wyvillethomsoni (Echinodermata) from the bathyal slope of the Bay of Biscay: Deep Sea Research, v. 28A, p. 441-453.

Donovan, S.K., 1984, Stem morphology of the Recent crinoid Chladocrinus (Neocrinus) decorus: Palaeontology, v. 27, p. 825-841.

Donovan, S.K., 1989, The improbability of a muscular crinoid column: Lethaia, $v$. 22 , p. 307-315.

Emson, R.G., and WILKIE, I.C., 1980, Fission and autotomy in echinoderms: Annual Review of Oceanography and Marine $\mathrm{Bi}$ ology, v. 8, p. 155-250.

GLUCHOWSKI, E., 1981, Stratigraphic significance of Paleozoic crinoid columnals from Poland: Zeszyty Naukowe Akademi Górniczej i Hutniczej, v. 7, p. 89-110.

Grimmer, J.C., and Holland, N.D., 1990, The structure and biology of a sessile, stalkless crinoid, Holopus rangii: Acta Zoologica (Stockholm), v. 71, p. 61-67.

GRIMMER, J.C., HollaND, N.D., and HAYAMI, I., 1985, Fine structure of an isocrinid sea lily (Metacrinus rotundus) (Echinodermata, Crinoidea): Zoomorphology, v. 105 , p. $39-50$.
Grimmer, J.C., Holland, N.D., and KuBota, H., 1984a, The fine structure of the stalk of the pentacrinoid larva of a feather star, Comanthus japonica (Echinodermata: Crinoidea): Acta Zoologica (Stockholm), v. 65, p. 41-58.

Grimmer, J.C., Holland, N.D., and MesSING, C.G., 1984b, Fine structure of the stalk of the bourgueticrinid sea lily $D e$ mocrinus conifer (Echinodermata: Crinoidea): Marine Biology, v. 81, p. 163176.

HAGDORN, H., 1983, Holocrinus doreckae n. sp. aus dem Oberen Muschelkalk und die Entwicklung von Sollbruchstellen in Stiel der Isocrinida: Neues Jahrbuch für Geologie und Paläontologie, Monatshefte, v. 6, p. 345-368.

HAGDORN, H., 1986, Isocrinus? dubius (Goldfuss, 1831) aus dem Unteren Muschelkalk (Trias, Anis): Zeitschrift für Geologische Wissenschaft, v. 14, p. 705727.

Holland, N.D., Grimmer, J.C., and WIEGEMANN, K., 1991, The structure of the sea lily Calamocrinus diomedae, with special reference to the articulations, $\mathrm{mi}$ crostructure, symbiotic bacteria, axial organs, and stalk tissues (Crinoidea, Millericrinida): Zoomorphology, v. 110, p. 115-132.

Llewellyn, G., and Messing, C.G., 1994, Compositional and taphonomic variations in modern crinoid-rich sediments from the deep water margin of a carbonate bank: Palaios, v. 8, p. 554-573.

MACURDA, D.B., Jr., and MEYER, D.L., 1974 Feeding posture of modern stalked crinoids: Nature, v. 247, p. 394-396.

MACURDA, D.B., Jr., and MEYER, D.L., 1975 The microstructure of the crinoid endoskeleton: University of Kansas Paleontological Contributions, Paper 74, p. $1-22$.

Messing, C.G., Rosesmyth, M.C., MaIleR, S.R., and MILLER, J.E., 1988, Relocation movement in stalked crinoids (Echinodermata): Bulletin of Marine Science, v. 42 , p. $480-487$.

MooRE, R.C., and Jefrords, R.M., 1968 Classification and nomenclature of fossil crinoids based on studies of dissociated parts of their columns: University of Kansas Paleontological Contributions, Echinodermata 9, p. 1-86.

Motokawa, T., 1984, Connective tissue catch in echinoderms: Biological Reviews, v. 59, p. $255-270$.

OJI, T., 1989, Growth rate of the stalk of Metacrinus rotundus (Echinodermata: Crinoidea) and its functional significance: Journal of the Faculty of Science,
University of Tokyo, Section II, v. 22, p. 39-51.

Rasmussen, H.W., 1977, Function and attachment of the stem in Isocrinidae and Pentacrinitidae: Review and interpretation: Lethaia, v. 10, p. 51-57.

Roux, M., 1974, Les principaux modes d'articulation des ossicules du squelette des crinoïdes pédonculés actuels. Observations microstructurales et conséquences pour l'interprétation des fossiles: Comptes Rendu des Academie de Science, Paris, Série D278, p. 2015-2018.

Roux, M., 1975, Microstructural analysis of the crinoid stem: University of Kansas Paleontological Contributions, Paper 75, p. 1-7.

Roux, M., 1977, The stalk joints of Recent Isocrinidae (Crinoidea): Bulletin of the British Museum (Natural History) (Zoology), v. 32, p. 45-64.

Roux, M., 1980a, Découverte de sites à crinoïdes pédonculés (genres Diplocrinus et Proisocrinus) au large de Tahiti: Comptes Rendu des Academie de Science, Paris, Série D290, p. 119-122.

Roux, M., 1980b, Les crinoïdes pédonculés (Échinodermes) photographiés sur les dorsales océaniques de l'Atlantique et du Pacifique: Comptes Rendu des Academie de Science, Paris, Série D291, p. 901904.

SCHUBERT, J.K., BotTJER, D.J., and SimMS, M.J., 1992, Paleobiology of the oldest known articulate crinoid: Lethaia, v. 25 , p. 97-110.

Simms, M.J., 1988, The phylogeny of postPaleozoic crinoids: in PaUL, C.R.C., and Smith, A.B., eds., Echinoderm phylogeny and evolutionary biology: Clarendon Press, Oxford, p. 269-284.

Simms, M.J., 1989, British Lower Jurassic crinoids: Monograph of the Palaeontographical Society, London, v. 142, p. 1103.

Stukalina, G.A., 1988, Studies in Paleozoic crinoid columnals and stems: Palaeontographica, v. 204, p. 1-66.

WILKIE, I.C., 1984, Variable tensility in echinoderm collagenous tissues: A review: Marine Behaviour and Physiology, v. 11, p. 1-34.

Wilkie, I.C., and Emson, R.H., 1988, Mutable collagenous tissues and their significance for echinoderm paleontology and phylogeny: in PAUL, C.R.C., and Smith, A.B., eds., Echinoderm phylogeny and evolutionary biology: Clarendon Press, Oxford, p. 311-330.

ACCEPTED FEBRUARY 4, 1994 
APPENDIX 1

Disarticulation patterns among fossil pluricolumnals.*

\begin{tabular}{|c|c|c|c|c|c|c|c|c|c|}
\hline \multicolumn{5}{|c|}{ Museum of Comparative Zoology } & \multicolumn{5}{|c|}{ United States National Museum } \\
\hline Catalog \# & Species & A & $\mathbf{B}$ & $\mathrm{C}$ & Catalog \# & Species & $\mathbf{A}$ & B & $\mathrm{C}$ \\
\hline 112 & Pentacrinus cingulatus & 60 & 58 & 6 & s2941 & Pentacrinus agassizi & 1 & 1 & 5 \\
\hline 2139 & P. tuberculatus & 24 & 24 & 9 & $\mathrm{~s} 2946$ & P. basaltiformis & 3 & 3 & 3 \\
\hline 1369 & $P$. cingulatus & 23 & 23 & 3 & s2945 & P. bajocensis & 3 & 3 & 6 \\
\hline 177 & $P$. cingulatus & 10 & 10 & 4 & s2947 & P. basaltiformis & 3 & 3 & 4 \\
\hline 3928 & $P$. cingulatus & 11 & 11 & 2 & 19510 & P. basaltiformis & 2 & 2 & 4 \\
\hline 128 & P. subteres & 11 & 11 & 2 & s2944 & $P$. cingulatus & 14 & 14 & 2 \\
\hline 2349 & P. subteres & 9 & 8 & 2 & $\mathrm{~s} 2953$ & $P$. nodulosus & 1 & 1 & 11 \\
\hline 9165 & P. annulatus & 6 & 6 & 6 & No \# & P. tuberculatus & 1 & 1 & 2 \\
\hline 741 & P. pentagonalis & 9 & 9 & 3 & s2954 & P. pentagonalis & 3 & 3 & 7 \\
\hline 761 & $P$. propinquus & 4 & 4 & 6 & No \# & P. pentagonalis & 4 & 2 & 6 \\
\hline 731 & P. basaltiformis & 14 & 14 & 3 & 19217 & P. pentagonalis & 43 & 30 & 2 \\
\hline No \# & P. scalaris & 6 & 6 & 4 & s2955 & P. priscus & 1 & 1 & 6 \\
\hline 2459 & P. scalaris & 6 & 6 & 4 & 6031 & $P$. sp. & 8 & 8 & 5 \\
\hline 129 & P. subteres & 8 & 7 & 3 & 9781 & P. basaltiformis & 3 & 3 & 8 \\
\hline 1773 & P. laevigatus & 1 & 1 & 2 & $\mathrm{~s} 2958$ & $P$. rupellens & 4 & 4 & 4 \\
\hline 2470 & P. scalaris & 8 & 8 & 5 & 23320 & $P$. saevigratis & 22 & 20 & 2 \\
\hline 743 & $P$. cingulatus & 10 & 9 & 7 & $\mathrm{~s} 2960$ & $P$. sigmariengesis & 2 & 2 & 2 \\
\hline 128 & $P$. carinatus & 1 & 1 & 7 & 1951 & P. tuberculatus & 4 & 3 & 6 \\
\hline 2309 & P. propinquus & 2 & 2 & 6 & $\mathrm{~s} 267$ & P. tuberculatus & 4 & 4 & 10 \\
\hline 1219 & P. agassizi & 4 & 4 & 3 & 194297 & $P$. cingulatus & 7 & 7 & 8 \\
\hline 3881 & $P$. sp. & 3 & 2 & 5 & 23319 & Isocrinus propiquus & 5 & 5 & 4 \\
\hline 1779 & P. subteres & 1 & 1 & 7 & s2974 & I. crista-galli & 3 & 3 & 6 \\
\hline 1221 & P. annulatus & 1 & 1 & 4 & s2973 & I. bavaricus & 17 & 16 & 5 \\
\hline 1389 & P. scalaris & 1 & 1 & 9 & & & & & \\
\hline 2450 & $P$. cingulatus & 3 & 3 & 4 & & & & & \\
\hline 2451 & P. subteres & 1 & 1 & 7 & & & & & \\
\hline 1478 & P. basaltiformis & 2 & 2 & 5 & & & & & \\
\hline 738 & $P$. sp. & 1 & 1 & 3 & & & & & \\
\hline 1470 & P. propinquus & 2 & 2 & 6 & & & & & \\
\hline 1217 & $P$. sp. & 2 & 2 & 8 & & & & & \\
\hline 949 & P. basaltiformis & 8 & 7 & 2 & & & & & \\
\hline
\end{tabular}

* Taxonomic assignments as on museum labels. A: Total number of pluricolumnals; B: number of nodal-terminating pluricolumnals; C: minimum number of columnals/pluricolumnal. 